\title{
Quality Management as a Strategic Tool to Enhance the Relationship between Leaders' Behavior and Lecturers' Job Satisfaction
}

\author{
Muhammad Naveed Jabbar ${ }^{1} \&$ Fauzi Hussin ${ }^{1}$ \\ ${ }^{1}$ University Utara Malaysia, Malaysia \\ Correspondence: Muhammad Naveed Jabbar, University Utara Malaysia, Malaysia. E-mail: \\ muhammad_naveed_j@ahgs.uum.edu.my
}

Received: April 4, 2018

Accepted: September 28, 2018

Online Published: May 10, 2019

doi:10.5430/ijhe.v8n3p36

URL: https://doi.org/10.5430/ijhe.v8n3p36

\begin{abstract}
From last two decades, the Higher Education institutions of the developing countries have also realized the importance of better quality services and leadership behavior. Previous studies investigated that better quality services and leadership behavior are fundamental tools for the enhancement of satisfaction level of the university lecturers. Like other business organizations, the education sector also required to adopt the new approaches and techniques for effective leadership. Pakistan is also trying to improve as an education hub amongst all the countries in this region and focusing to render the quality of services according to the perception and expectations of the staff. The objective of this paper is to determine the intervening role of service quality management on the relationship between leadership behavior and job satisfaction. This research study based on quantitative in its nature. The lecturers of public universities in Punjab, Pakistan were a population of the study. Total 396 public university lecturers were selected as sample for the delimitation of the population from public universities and stratified random sampling technique was adopted for collection data. 15\% proportionate was adopted to select the sample of the study. A survey method was used to collect the data from the respondents by questionnaire. Data was entered in sheets for analysis using smart PLS-SEM 3 (Partial Least Square). The findings of the study show that leader's behavior has significance effect on job satisfaction whereas, service quality management has significance-mediating role on the relationship between leadership behavior and job satisfaction.
\end{abstract}

Keywords: leader's behavior, quality management, job Satisfaction

\section{Introduction}

Service quality management is a degree of perfection but it is also a structured and systemic process for enhancing service level. Therefore, education level must meet all requirements needed for better social change. The basic question about the quality management is why we need this system in our education sector: are we satisfied with the standard of existing quality? If the answer is no, we need to raise the benchmark? If the answer is yes, then we need to follow the standards of quality management from minimum level and try to raise them gradually. Implementation of quality management process in education means to justify the existence of educational system to all stakeholders and ultimately the society in the broader sense of global society (Chui et al., 2016). Behavior of the leader is a major organ and the most dominant feature for the achievement of value in higher education. Therefore, leadership and quality management smoked connectedly (Gallear, D., et, al., 2012). The degree of perfection regarding job determined the better quality services that rendered an institution towards the employees. Better quality of services has significant impact on the job satisfaction. The satisfaction of employees plays a dynamic participation for the development of any business organization and education institutions as well. However, institutions concentrate on employee salary package, working condition, fringe and contingent benefits for the development of satisfaction level (Kabak, K. E. et, al., 2014).

\section{Literature Review}

A worldwide acknowledgment is growing that the importance of knowledgeable and skillful human capital is more valuable than the physical capital of a country. This leads to greater demands from the higher education sector to develop the human resources that could lead the country on the path of development (Government of Pakistan, 2014). Education is one of the most crucial factors to strengthen the social and economic growth of the country and empowering generation with skills and knowledge. Quality education plays significance role for the development of 
the nation's to the emergence of global competition in education and technology in 21th century (Awan \& Zia, 2015). Quality is the main, essential and the most eminent characteristic with which an institution can observe and guarantee about its maintenance and improvement of its education standard (Saeed, 2014). Quality is a constant process of developing and sustaining relationships by assessing, anticipating and the needs. The educational standards can be improved and maintained via quality of education around the world (Sellis, 2014). Frank (2009) suggested that positive attitude and relation of the leadership towards lecturers enhance the confidence level. Leaders should provide accommodation and positive instructions to the employees so that they can assume ever changing in the field of education. He must focus on gratitude and determination of the problem as well as augmented cooperation between leader and lecturers. Simon (2011) believed that leader must persuade encouraging employees to participate in the collective and mutual decision-making process. It can provide leader with the essential tools to actively prime disputes regarding instructions, curriculum and assessment. The better employment opportunities provide the best job security to the lecturers. These opportunities give maximum time for the improvement of proficiencies especially in the field of profession. Watts (2009) stated that self-efficacy is an important factor for increasing the satisfaction level of the employees. The employees focus on the self-respect greater than compensation. Democratic behaviour of the leader is the best source for increasing the satisfaction level of the employees. Golia, Belias, Tsioli and Koustelios (2013) explained that leadership behaviour and satisfaction have curtain sphere between each other. The performance and satisfaction of the employees direct relates to the positive behaviour of the leadership. Hemeric et, al. (2010) suggested that leader is considered as a role model among the employees. Development of the mutual understanding between leader and employees is a good sign for the progress of the educational institution. Sargent and Hannum (2005) said that supervision exposes with the leadership skill and proficiency, job awareness and fair-mindedness. Every institution focuses on the training and ability of their employees. The whole work of the institution is unable to handle one person. It can only possible effectively within the mutual understanding and cooperation of all the members. The employees are considered as a web partner of the institution. Barnes and Conti (2009) explained that the positive behaviour and relationship between the leadership and employees enhance the level of satisfaction of the employees. (Leithwood, 2006) argued that the friendly environment and supportive behaviour of leadership creates good working environment among the institution. It can develop the performance of the employees. The job discrepancies and positive attitude of the leadership towards employees increase the production of an organization.

\subsection{Path-Goal Theory of Leadership}

Path-goal theory is the process by which leaders motivate their followers to accomplish designated objectives (Northouse, 2015). This theory focuses on the process of enhancing employee's satisfaction through motivation (House, 1996). This theory stresses on the correlations between the leadership, the distinctive qualities of the employees and the working condition (Bess \& Goldman, 2001). According to Northouse (2010) the three variables constituting path-goal theory can be achieved through the use of leadership behavior that best meets followers' motivational needs, in their work environment. Indvik (1988) contends that leaders always focus on the social needs of the employees and giving the rewards after successful completion of the tasks. House and Mitchell (1974) stated that leaders always create a chance to increase the salary and promotion of the employees so that the common objectives can be achieved. Northouse (2010) adds that, followers get motivated when their leaders help them to advise them right path to the goal and planned informal working process. Indvik (1988) concludes that removing working hindrances for goals attainment, and making the work itself more satisfying all. Northouse (2010) state that it suggested how leaders guide and help the subordinates for the completion of the organizational objectives, and adopt the positive attitudes towards them. It is a result the employees perform well with satisfaction. Bess and Goldman (2001) add that in a situation where employees are working with target goals, it is appropriate for the leader to choose the best leadership behavior that increase followers' expectations for success and in achieving the stated goals.

\subsection{Application of Path-Goal Theory}

Path-goal is also pragmatic approach for effective leadership attitude not just for theoretical intricate (House, 1996). It provides the best strategies and techniques to the leaders for taking the good work from the subordinates. It based on the supportive and non-supportive attitudes of the leader towards employees for satisfaction (Northouse, 2010). This theory provides a guideline to the leader how he can interact with the employees and taking positive action with good behavior for the satisfaction of the workers (Bass \& Riggio, 2006). Path-goal theory helps the leaders how he can eradicate the communication gap between the employees and focus on the social needs of the employees (House, 1996). 
Northouse (2010) asserted that, these components are leader's behavior and follower's behavior which is based on supportive and non-supportive behavior of the leader and followers. House (1996) state that, path-goal theory helps to make the leader successful for using the different techniques according to the working environment. House (1996) further add that, the theory postulated that particular leadership behavior is needed as motivating factor to followers which is serves as contingent on the followers' behavior and the task completion. This means that, leadership behavior of a leader is a motivating factor in employee behavior towards task accomplishment (Northouse, 2010).

\subsection{Lecturers' Job Satisfaction}

Newsome (2008) explained that Employees' satisfaction based on the psychosomatic attitude of an individual towards a job in different times. The topographies of job satisfaction that make employees emotionally relax. These are work environment, pay \& promotion and compensation. Employees' satisfaction is a functioning response to the situation that an individual gets during job hours. The working condition and satisfaction has eminent relationship. Empowerment and self-efficacy are important elements to check the satisfaction level of the employees. Maher (2013) claims that job satisfaction covers how much an employee enjoys work and the affective feeling of staff towards their job. This could be the employees feeling towards specific aspects of their job with their pay, relationship with colleagues and working conditions ( $\mathrm{Lu}, 2005)$. Job satisfaction level may be determining the extent to which work outcomes meet or exceed expectations. Spector explained that

Employee satisfaction on the job or the extent is to which state employees like his job. Feelings and expectations of the employees mostly shows the satisfaction, the overall assessment of work process is also depending upon the satisfaction of the employees. The work environment of the job is also depending upon the performance of the employees and best performance an important factor for the job satisfaction. Employee satisfaction is an important element in any organization. Employee satisfaction in service organizations achieved in the internal satisfaction. Lecturers who are satisfied are employees who are motivated to convey his concern for others (Schermerhorn, 2011). Positive reinforcement of employees will increase employees' satisfaction who has served. The past studies suggested that employee satisfaction mainly based on the social exchange Theory. The rewards based on the social need of the employees are best source for the satisfaction of the employees (Daneshfard, C. \& Ekvaniyan, K.E., 2012).

\subsection{Herzberg's Duality Theory of Satisfaction}

Herzberg's duality theory of satisfaction is one of the emerging theories from its context. Particularly, the studies have been conducted to examine the satisfaction in higher education among the customers and employees and suggested that satisfaction is an important tool for the development of institutions. In 1959 Herzberg's published a book a title "The Motivation to Work" he wrote in the book that an individual's performs well during his job hours when they feel satisfaction. Behling, Labowitz, and Kosmo, (1968) stated that Herzberg's duality theory is a more conservative uniscalar slant to determine the satisfaction. The Hrzberg's (1959) classified the factors of motivators and hygiene. The research was conducted on interview based to investigate the satisfaction of the employees. Motivators were the satisfying events described in the interviews. The factors were included in this study were recognition, achievement, responsibility, work itself, growth and advancement. The result of the study showed that the employees uttered negative response on satisfaction regarding these factors: organizational policy and administration, relationship with supervisor, work operating conditions, pay \& promotion, fringe and contingent benefits, empowering employees, relationships with leadership, relationships with subordinates, status and security. Herzberg proclaimed that these factors stressed on external work context and motivation relates with the internal states of mind. Thereafter, Herzberg suggested the theory of job satisfaction with the traditional conception of factors impacting employees on a uniscalar continuum. For example, pay and promotion, fringe and contingent benefits, effective supervision and effective institutional policy raise the satisfaction level of the employees. Herzberg further suggested that without develop the motivation it will be unable to increase the satisfaction level. Absence of motivation creates the lack of satisfaction. For example, without achievement or recognition it is impossible to develop the satisfaction (Ewen, 1964).

\subsection{Research Hypothesis}

H1. There is a significant effect of the Leader's behavior on job satisfaction.

$\mathrm{H} 2$. There is a significant effect of the Leader's behavior on quality management.

$\mathrm{H} 3$. There is a significant effect of Quality management on job satisfaction.

H4. Quality management mediates the relationship between leader's behaviors and job satisfaction. 


\subsection{Conceptual Framework}

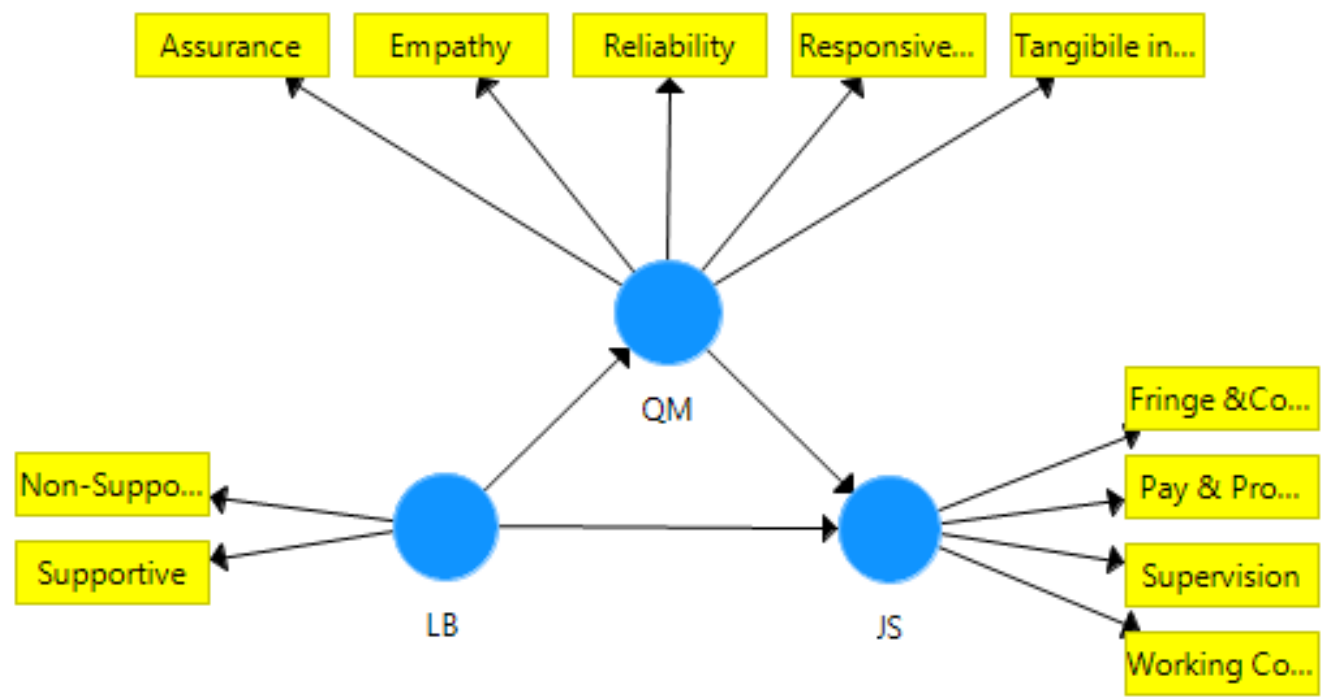

Figure 1. Conceptual framework of the study

\section{Methodology}

The current study was designed by using the quantitative approach for which survey research method was used to conduct this study. The public university lecturers from Punjab, Pakistan were population of the study. Four universities were selected as sample of this research for the delimitation of the population. The total 396 lecturers were selected as a sample of this study. Stratified Random sampling technique was adopted for the data collection from the respondents by questionnaire. 15\% proportionate was adopted to select the sample of the study from each strata (university). The questionnaire of quality management was comprised on Parasuraman's (1991) service quality management dimensions with reliability 0.85 , leadership behavior from stogdil (1963) with 0.87 and the questionnaire of job satisfaction adopted from (Lester, P. E. 1987) with 0.88 reliability index. The dimensions included in service quality management were tangibility, reliability, responsiveness, assurance, empathy and in leadership behavior were supportive behavior and non-supportive behavior, whereas in job satisfaction were supervision, working condition, pay \& promotion and fringe \& contingent benefits. A survey method was adopted for data collections from the respondents by questionnaire. Seven points scale (SA 1 to SDA 7) was assumed to accumulate the data from respondents. Smart PLS-3 (SEM) software used for analysis. The descriptive and inferential statistics was used for data analysis i.e. mean and standard deviation, path coefficient (direct effect) and specific indirect effect (mediating analysis). 


\section{Findings}

Table 1. Demographic analysis

\begin{tabular}{llll}
\hline Demographics & Categories & Frequency & $\%$ \\
\hline University & PU & 215 & 54.3 \\
& LCWU & 86 & 21.7 \\
& UE & 30 & 7.6 \\
& UOS & 65 & 16.4 \\
\hline Gender & Male & 156 & 39.4 \\
& Female & 240 & 60.6 \\
\hline Designation & Lecturer & 130 & 32.8 \\
& Assistant Prof. & 183 & 46.2 \\
& Associate Prof. & 72 & 18.2 \\
\hline Qualification & Professor & 11 & 2.8 \\
\hline Master & 11 & 2.8 \\
& M. Phil & 141 & 35.6 \\
& Ph. D & 224 & 56.6 \\
& Post Doctorate & 20 & 5.1 \\
\hline Job Experience & 1-5 years & 159 & 40.2 \\
& 6-10 years & 110 & 27.8 \\
& 11-15 years & 23 & 5.8 \\
& $>15$ years & 159 & 40.2 \\
\hline
\end{tabular}

\section{Measurement Model}

Measurement model examined constructed on PLS-SEM with the help of Smart PLS-3.0 (Ringle, Wende \& Becker, 2015). For the assessment of measurement model, there was conducted composite reliability, discriminant validity and factor loading. Table 2 indicates the values of factor loading and reliability. George and Mallery (2003) suggested that the reliability 0.7 or above is acceptable for the research. In this study, it is valuable. Additionally, composite reliability should be 0.7 or above (Fornell \& Larcker, 1981; Hair \& Lukas, 2014). Moreover, according to Chin (1999) the recognition value of factor loading 0.6 or above is satisfactory.

Table 2. Factor analysis

\begin{tabular}{lllll}
\hline Variables & Dimensions & Items & Loading & Reliability \\
\hline Leadership Behavior & Supportive Behavior & SB1 & .70 & .77 \\
& SB2 & .68 & \\
& SB3 & .62 & \\
& SB4 & .70 & \\
\cline { 2 - 4 } & SB5 & .71 & \\
& SB6 & .69 & \\
& NSB1 & .66 & .81 \\
& NSB2 & .63 & \\
& NSB3 & .70 & \\
& NSB4 & .67 & \\
& NSB5 & .72 &
\end{tabular}




\begin{tabular}{|c|c|c|c|c|}
\hline & & NSB6 & .71 & \\
\hline & & NSB7 & .70 & \\
\hline Quality Management & Tangible Infrastructure & $\mathrm{T} 1$ & .83 & \\
\hline & & $\mathrm{T} 2$ & .89 & .95 \\
\hline & & $\mathrm{T} 3$ & .88 & \\
\hline & & $\mathrm{T} 4$ & .91 & \\
\hline & & $\mathrm{T} 5$ & .91 & \\
\hline & & T6 & .94 & \\
\hline & & $\mathrm{T} 7$ & .87 & \\
\hline & Assurance & A1 & .91 & \\
\hline & & A2 & .67 & .91 \\
\hline & & A3 & .90 & \\
\hline & & A4 & 66 & \\
\hline & & A5 & .89 & \\
\hline & & A6 & .67 & \\
\hline & & A7 & .91 & \\
\hline & Reliability & $\mathrm{R} 1$ & .72 & \\
\hline & & & & .78 \\
\hline & & $\mathrm{R} 2$ & .67 & \\
\hline & & $\mathrm{R} 3$ & .68 & \\
\hline & & $\mathrm{R} 4$ & .71 & \\
\hline & & $\mathrm{R} 5$ & .70 & \\
\hline & & R6 & .66 & \\
\hline & Responsiveness & RE1 & .61 & .72 \\
\hline & & RE2 & .68 & \\
\hline & & RE3 & .65 & \\
\hline & & RE4 & .69 & \\
\hline & & RE5 & .70 & \\
\hline & & RE6 & .66 & \\
\hline & Empathy & E1 & .77 & .75 \\
\hline & & E2 & .70 & \\
\hline & & E3 & .67 & \\
\hline & & $\mathrm{E} 4$ & .72 & \\
\hline & & E5 & .67 & \\
\hline Job Satisfaction & Supervision & S1 & .68 & .77 \\
\hline & & S2 & .68 & \\
\hline & & S3 & .67 & \\
\hline & & S4 & .71 & \\
\hline & & S5 & .65 & \\
\hline & & S6 & .69 & \\
\hline & Working Condition & $\mathrm{WC1}$ & .66 & .79 \\
\hline
\end{tabular}




\begin{tabular}{|c|c|c|c|}
\hline & $\mathrm{WC} 2$ & .63 & \\
\hline & WC3 & .67 & \\
\hline & WC4 & .68 & \\
\hline & WC5 & .71 & \\
\hline & WC6 & .64 & \\
\hline & WC7 & .72 & \\
\hline Pay \& Promotion & PP1 & .66 & .74 \\
\hline & PP2 & .68 & \\
\hline & PP3 & .63 & \\
\hline & PP4 & .72 & \\
\hline & PP5 & .66 & \\
\hline & PP6 & .64 & \\
\hline Fringe \& Contingent & $\mathrm{FC} 1$ & .65 & .73 \\
\hline & $\mathrm{FC} 2$ & .73 & \\
\hline & FC3 & .77 & \\
\hline & $\mathrm{FC} 4$ & .72 & \\
\hline & FC5 & .61 & \\
\hline
\end{tabular}

\section{Discriminant validity}

The discriminant validity was analyzed to determine the model external consistency. There are three criteria to validate the discriminant validity such as Fornell and Larcker, cross loading and Heterotrait-Monotrait ratio of correlations (HTMT).

According to Fornell and Larcker (1981) stated that the value of the variables was compare with the square root of AVE's. Finally, as explained in table 3 all the correlations among the variables are lower than square root-averages (AVEs) as which are bolded in crosswise.

Table 3. Fornell and Larcker

\begin{tabular}{llll}
\hline Variable & JS & LB & QM \\
\hline Job Satisfaction & 0.820 & & \\
Leadership Behavior & 0.587 & 0.764 & \\
Quality Management & 0.652 & 0.547 & 0.651 \\
\hline
\end{tabular}

Moreover, the Heterotrait-Monotrait ratio of correlations (HTMT) is a new method for assessing discriminant validity in PLS-SEM, which is one of the key building blocks of model evaluation (Henseler, Ringle \& Sarstedt, 2009). criminant validity is not established, researchers cannot be confirmed that the results of structural model are real, or whether they are merely the result of statistical inconsistencies. The HTMT criterion clearly outperforms standard approaches to discriminant validity assessment such as Fornell and Larcker criterion and cross-loadings, which are largely unable to detect a lack of discriminant validity (Hair et al, 2013). However, HTMT ratio should not be more than one (1), thus current study found the all HTMT values less than one (1) and validated all study constructs discriminant validity, results of HTMT values can be seen in table 4 . 
Table 4. HTMT

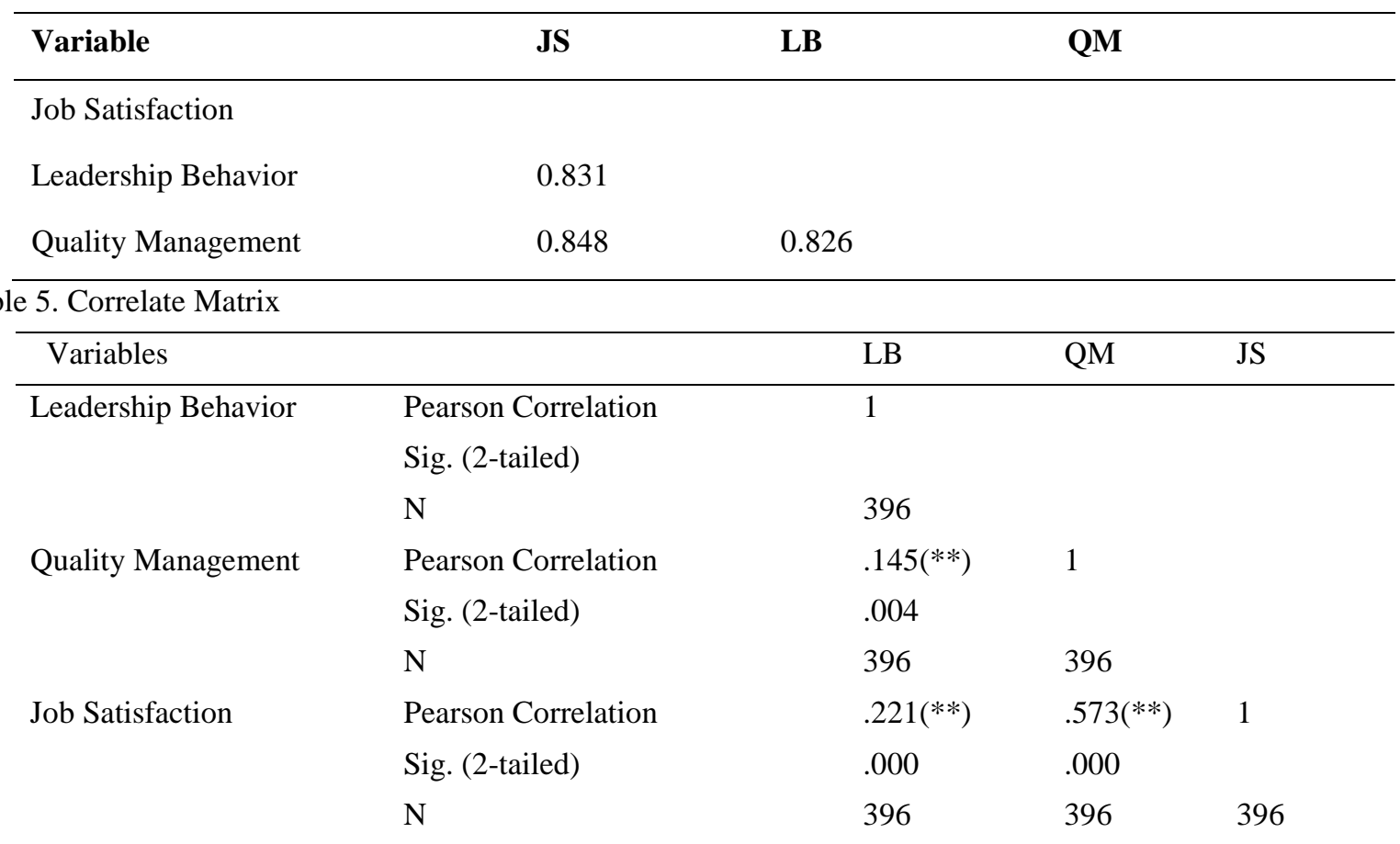

** Correlation is significant at the 0.01 level (2-tailed).

Correlate analysis was conducted between leader's behavior, quality management and job satisfaction. The statistical result found that leader's behavior and job satisfaction have moderate positive relationship with $(r=.221$, sig=.00) whereas quality management and job satisfaction have strong positive relationship with $(\mathrm{r}=.573$, sig=.00). The $\mathrm{R}$ value .0 to .2 is considered weak relationship, 0.21 to 0.4 moderate and 0.5 to 0.9 strong relationship. The present study shows there is a significant relationship between the variables in table 5 .

\section{Structural model assessment}

Structured model assessment used with the help of Smart PLS-3.0 to analyze the direct and indirect effect of the latent variables based on hypothesis. The hypothesis tested by considering the path coefficient and indirect specific effect with "t" value. Furthermore, effect size $\left(f^{2}\right)$, predictive relevance $\left(R^{2}\right)$ and cross-validated redundancy $\left(Q^{2}\right)$ were examined. However, Table 6 shows the effect size $\left(f^{2}\right)$. Cohen (1988) described that $f^{2}$ values of 0.02 is small, 0.15 is moderate and 0.35 is strong. In the current study, the $\mathrm{f} 2$ for all the variables is moderate. According to Cohen, West and Aiken (2013) the value of R2 0.00 to 0.25 is weak, 0.25 to 0.50 moderate and o.70 strong. Table 6 shows that the R2 value is 0.30 and 0.50 , It shows that by placing all the variables collectedly have predictive relevance $\left(R^{2}\right)$ is 0.30 to 0.50 that is moderate and cross-validated redundancy $\left(Q^{2}\right)$, by Chin (1998) and Henseler, Ringle \& Sinkovics (2009) it should be greater than zero.

In this paper there were three direct hypotheses as shown in Table 7 (H1, H2, H3) where accepted as the t-value was greater than 1.96. Additionally, PLS (SEM) bootstrapping was examined to test the mediation effect. Hair et al., (2014) stated that it is one of the appropriate procedures to analyzing through the small sample.

Furthermore, the endorsements of Hair et al., (2014), while testing the mediation effect, the procedure of Preacher and Hayes $(2004,2008)$ followed and the in-direct effect was examined. Henceforth, Table 8 spectacles the findings of mediation analysis (H4). It is acceptable that t-value is above than 1.96. Therefore, the mediation effect is significant in table 8 . Hence, all the hypothesis were accepted.

Table 6. Effect size $\left(f^{2}\right)$, predictive relevance $\left(R^{2}\right)$ and cross-validated redundancy $\left(Q^{2}\right)$

\begin{tabular}{lcll}
\hline Exogenous Variable & $\boldsymbol{f}^{2}$ & $\boldsymbol{R}^{2}$ & $\boldsymbol{Q}^{2}$ \\
\hline Leadership Behavior & 0.15 & & 0.30 \\
Quality Management & 0.31 & 0.30 & \\
Job Satisfaction & & 0.50 & \\
\hline
\end{tabular}




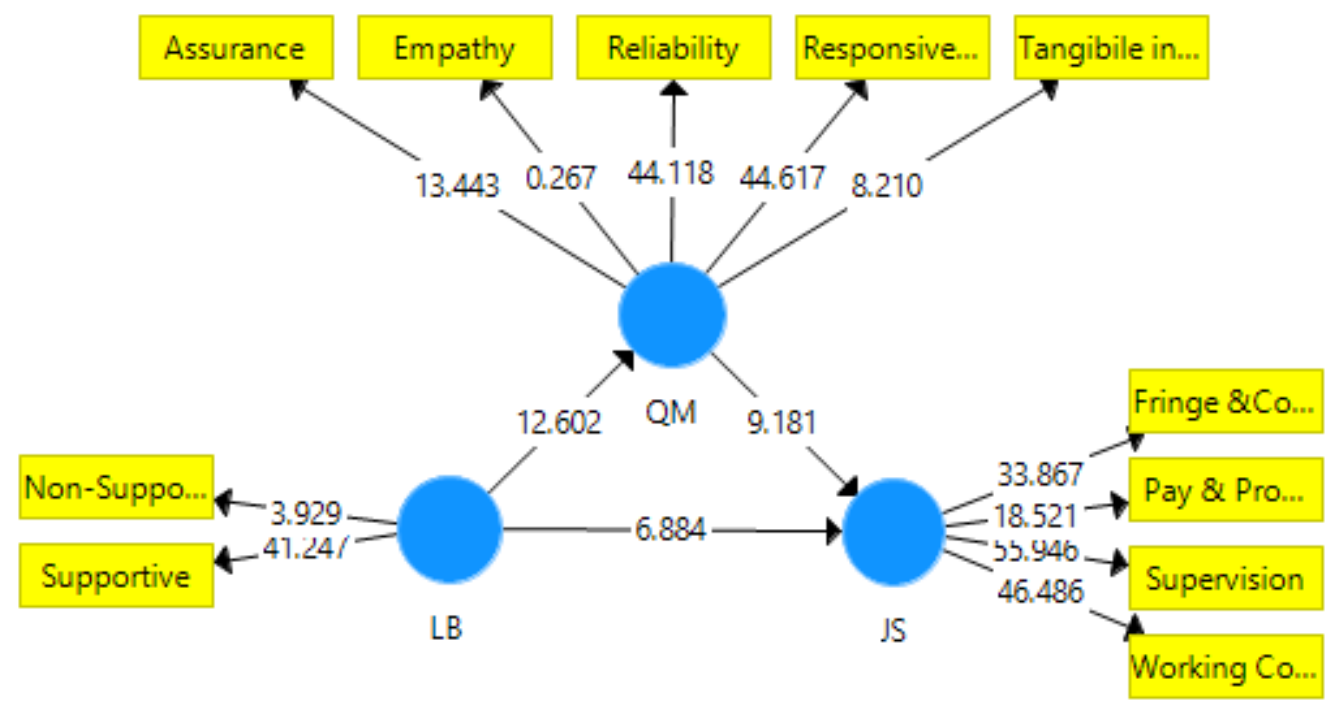

Figure 2. Structure Model Assessment

Table 7. Path Coefficient (Direct Effect)

\begin{tabular}{llllll}
\hline Hypothesis & Beta & SD & T-Value & P-Value & Decision \\
\hline H1. LS $\rightarrow$ JS & 0.36 & 0.07 & 5.13 & 0.00 & Supported \\
H2. LS $\rightarrow$ QM & 0.53 & 0.09 & 5.67 & 0.00 & Supported \\
H3. QM $\rightarrow$ JS & 0.45 & 0.04 & 9.97 & 0.00 & Supported \\
\hline
\end{tabular}

Table 8. Specific indirect Effect (Mediating effect)

\begin{tabular}{llllll}
\hline Hypothesis & Beta & SD & T-Value & P-Value & Decision \\
\hline $\mathrm{H} 4 . \mathrm{LS} \rightarrow \mathrm{QM} \rightarrow \mathrm{JS}$ & 0.24 & 0.04 & 4.96 & 0.00 & Supported
\end{tabular}

\section{Conclusion and Discussion}

It was concluded that there was a positive significance relationship between the leader's behavior and service quality management with job satisfaction. There was a positive significance effect of leader's behavior on service quality management and job satisfaction whereas, service quality management has its significance mediating role on relationship between leadership behavior and job satisfaction (Chui et al., 2016, Golia, Belias, Tsioli and Koustelios, 2013). This study is helpful for the leaders, managers, educationist and administrative to focus on the leadership practices for the development of the higher education institutions. It is suggested that the research studies should be conducted between public and private education institutions. The seminar and workshops should be conducted in different areas of the country for the awareness of organization leadership strategies and job satisfaction for the enhancement of quality management. It was investigated that service quality management and leadership behavior are major factor for the enhancement about satisfaction of the university lecturers. Furthermore, there should be adopted more variables like assessment, decision-making participation and continuous process of quality for determine the job satisfaction. This study should be conducted between two developing countries and also between developing and developed countries. The future research should escalation the sample sizes, geographical range and organization type.

\section{References}

Barnes and Conti Associates. (2009). Building working relationships: Constructive engagement, negotiation and conflict management.

Bass, B. M., \& Riggo, R. E. (2006). Transformational Leadership (2nd ed.). Mahwah, NJ: Lawrence Erlbaum.

Behling, O., Labovitz, G., and Kosmo, R. (1968). The Herzberg controversy: A critical reappraisal. Academy of Management Journal, 11(1), 99-108. https://doi.org/10.5465/255200 
Bess, J. L., \& Goldman, P. (2001). Leadership Ambiguity in University and K-12 Schools, the Limits of Comporary Leadership Theory. B Leadership Quarterly, 12, 419-450. https://doi.org/10.1016/S1048-9843(01)00090-X

Brown, E. A. (2008). Dimensions of transformational leadership and relationship with employee performance in hotel front desk staff.

Chin, W. W. (1998). Commentary: Issues and opinion on structural equation modeling. MIS Quarterly, 22(1), vii-xvi.

Chin, W. W., \& Newsted, P. R. (1999). Structural equation modeling analysis with small samples using partial least squares. Statistical strategies for small sample research, 1(1), 307-341.

Chui, T. B., \& bin Ahmad, M. S. (2016). Evaluation of Service Quality of Private Higher Education Using Service Improvement Matrix. Procedia-Social and Behavioral Sciences, 224, 132-140. https://doi.org/10.1016/j.sbspro.2016.05.417

Daneshfard, C. \& Ekvaniyan, K.E. (2012). Organizational commitment and job satisfaction in Islamic Azad university. Interdisciplinary journal of Contemporary Research in Business, 3(9), 168-181.

Devos, G., Tuytens, M., \& Hulpia, H. (2014). Lecturers' organizational commitment: Examining the mediating effects of distributed leadership. American Journal of Education, 120, 205-231. https://doi.org/10.1086/674370

Ewen, R. (1964). Some determinants of job satisfaction: A study of the generality of Herzberg's theory. Journal of Applied Psychology, 48(3), 161-163. https://doi.org/10.1037/h0048383

Fornell, C., \& Larcker, D. F. (1981). Evaluating structural equation models with unobservable variables and measurement error. Journal of marketing research, 18(1), 39-50. https://doi.org/10.1177/002224378101800104

Frank, A., Elisabeth, G., John, W. M. \& Sheila, R. F. (2009). Studies of team teaching in the open space school. Interchange Journal, 3(2), 85-101. https://doi.org/10.1007/BF02137637

Gallear, D., Aldaweesh, M., \& Al-Karaghouli, W. (2012). The relationship between total quality management implementation and leadership in the Saudi higher education: a review and conceptual framework.

George, D., \& Mallery, M. (2003). Using SPSS for Windows step by step: a simple guide and reference. Boston: Allyn \& Bacon.

Golia, A.K., Belias, D.A., Tsioli, S., \& Koustelios, A. (2013). Organizational Culture and Leadership in Education

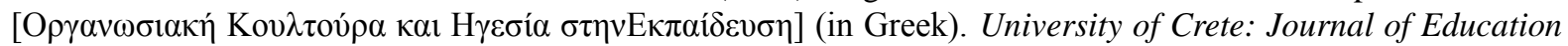
Sciences, 1-2, 15-31.

Hair, J. F., Ringle, C. M., \& Sarstedt, M. (2013). Partial least squares structural equation modeling: Rigorous applications, better results and higher acceptance. https://doi.org/10.1016/j.lrp.2013.01.001

Hair Jr., J. F., \& Lukas, B. (2014). Marketing research. Australia: McGraw-Hill Education.

Hemric, M., Schools, W. C., Boone, N., Boiling Springs, N., \&Shellman, D. (2010). Correlation between perceived teacher empowerment and perceived sense of teacher self- efficacy. Best practice, 37-43.

Henseler, J., Ringle, C. M., \& Sinkovics, R. R. (2009). The use of partial least squares path modeling in international marketing. In New challenges to international marketing, (Advances in International Marketing, Volume 20) (pp. 277-319). Emerald Group Publishing Limited.

Henseler, J., \& Sarstedt, M. (2013). Goodness-of-fit indices for partial least squares path modeling. Computational Statistics, 28(2), 565-580. https://doi.org/10.1007/s00180-012-0317-1

Hertzog, M.A. (2008). Consideration in Determing Sample size for pilot study. Research in Nursing and Health, 31(2), 180-191. https://doi.org/10.1002/nur.20247

Herzberg, F. (1966). Work and the Nature of Man, World Pub. Co, Cleveland. EXAMINING HERZBERG'S THEORY 249.

Herzberg, F. (1987). One more time: How do you motivate employees? Harvard Business Review September-October, 109-120.

Herzberg, F., Mausner, B., \& Snyderman, B.B. (1959). The Motivation to Work. New York: John Wiley \& Sons.

Herzberg, F., Mausner, B., \& Snyderman, B. B. (1959). The Motivation to Work (2nd edn).

Herzeberg, F. (1996). The Motivation to Work (6th. ed.). New York: John Willey and Sons.

House, R. J. (1996). Path-goal theory of Leadership: Lessons, legacy, and a reformulated theory. Leadership 
Quarterly, 7(3), 323-352. https://doi.org/10.1016/S1048-9843(96)90024-7

House, R. J., \& Mitchell, R. R. (1974). Path-goal Theory of Leadership. Journal of Contemporary Business, 3, 81-97.

Indvik, J. (1988). A More Completing Testing of Path-goal Theory. Paper presented at the Academic of Management, Anaheim, CA.

Kabak, K. E., Şen, A., Göçer, K., Küçüksöylemez, S., \& Tuncer, G. (2014). Strategies for employee job satisfaction: A case of service sector. Procedia-Social and Behavioral Sciences, 150, 1167-1176. https://doi.org/10.1016/j.sbspro.2014.09.132

Leithwood, K. (2006). Teacher working conditions that matter: Evidence for Change. Toronto: University Avenue. Elementary Lecturers ${ }^{\text {ee }}$ Federation of Ontario.

Lu, H., While, A.E. \& Barriball, K.L. (2005). Job satisfaction among nurses: a literature review. International Journal of Nursing Studies, 42(2), 211-238. https://doi.org/10.1016/j.ijnurstu.2004.09.003

Maher, E. (2013). Overcoming Controllable and Uncontrollable Work Difficulties: Change Environment. Deakin: Deakin University press.

Newsome, M., Moyes, G., Shao. L. (2008). Comparative analysis of employee job satisfaction in the accounting profess sion. Journal of Business \& Economics Research-February, 6(2), 65-81.

Northouse, P. G. (2010). Leadership Theory and Practice. (5ft ed.) Thousand Oaks, CA: SAGE Publications.

Northouse, P. G. (2015). Introduction to Leadership Concept and Practice. (3rd ed.) Thousand Oaks, CA: SAGE Publications.

Preacher, K. J., \& Hayes, A. F. (2004). SPSS and SAS procedures for estimating indirect effects in simple mediation models. Behavior research methods, instruments, \& computers, 36(4), $717-731.767$. https://doi.org/10.3758/BF03206553

Preacher, K. J., \& Hayes, A. F. (2008). Asymptotic and resampling strategies for assessing and comparing indirect effects in multiple mediator models. Behavior research methods, 40(3), 879-891. https://doi.org/10.3758/BRM.40.3.879

Ringle, C. M., Wende, S., \& Becker, J. M. (2015). Smart PLS 3. Boenningstedt: Smart PLS GmbH http://www.smartpls.com.

Saeed, M. M. \& Asghar, M. A. (2012). Examining the relationship between training, motivation and employees job performance: The moderating role of person job fit. Journal of basic and applied scientific research, 2(12), 12177-12183.

Sargent, T. \& Hannum, E. (2005). Keeping lecturers' happy: Job satisfaction among primary school lecturers' in rural northwest China. University of Pennsylvania. Survey of Children and Families Papers. https://doi.org/10.2307/3542162

Schermerhorn, J. R., Hunt, J. G., Osborn, R. N. \& Uhl-Bien, M. (2011). Organizational behavior. (11th ed.). Asia: John Wiley \& Sons, inc.

Simon (2011). What is job security and does it really exist? Retrieved from www.simonstapleton.com/wordpress/2011/02/12/what-is-job-security-and-does-it-really exist.

Watts, D. (2009). Enabling school structure, mindfulness, and teacher empowerment: Test of a theory (doctoral dissertation). University of Alabama, Tuscaloosa, AL. 